\title{
Social Aspect Of Globalization And Internationalization Of Socio-Economic Development
}

\author{
Ahmed Ali Brohi \\ \& \\ Saima Sheikh \\ Department of Sociology \\ University of Sindh, Jamshoro
}

\begin{abstract}
Globalization is characterized with multi-faceted aspects. Sometimes it helps in social and economic development. On the contrary, it hampers social and economic development on the whole. Globalization increases interdependency; therefore, it is the main cause of changes in the international system. Before the advent of globalization within the international spectra, the individual's role and status were considered important. With the introduction of globalization, individual activities regarding the interdependency between the nations have become collective efforts. Therefore, the concepts of social and economic development have changed entirely. These concepts, directly or indirectly, reshaped or sometimes totally converted into the lobbies and whims of multinational corporations, non-governmental organizations (NGOs) and global actors. This paper will review the process of globalization and its impact on international relations which is a factor in socio-economic development.
\end{abstract}

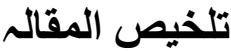

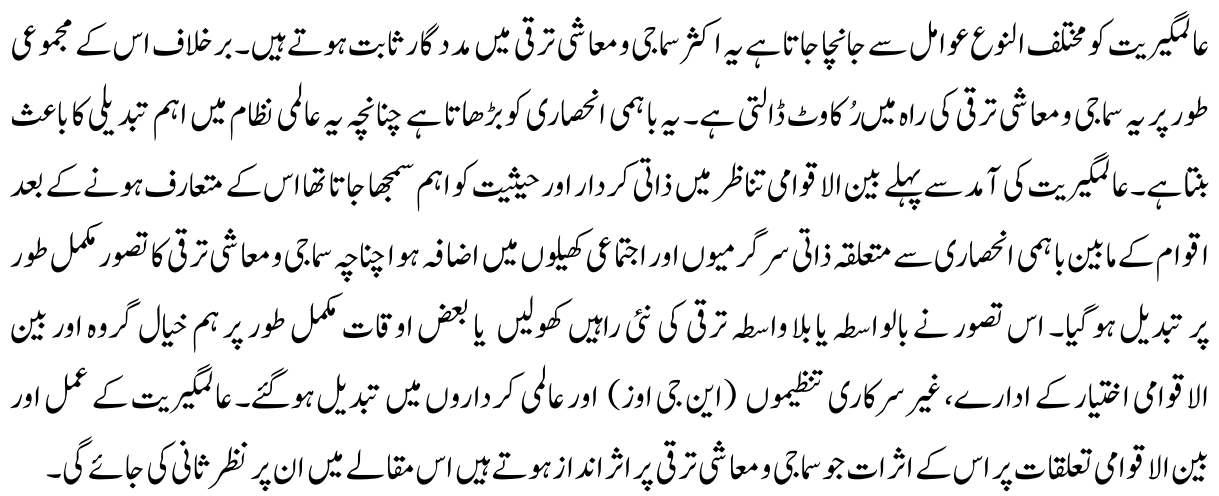

\section{Introduction}

Globalization and its overall impact on the economy and social development of the world is one of the hot issues discussed at various academic forums. Globalization in a literary sense is the tool of globalizing; transforming something in to a global phenomena. Generally, it is considered a holistic process in which the people of the world are unified 
into a single society and function together. This process on the whole is a combination of economic, technological, socio-cultural and political forces (Croucher, 2004). The importance of globalization in ushering socio-economic development was realized specially since last three decades when electronic media converted the world into a global village (Modelski, 1972).

In recent times, globalization coincided within the economic concept where the integration of national economies with the international economy has taken place through trade, foreign direct investment, capital flows, migration and the spread of technology (Bhagwati, 2004). As a result the issue of its expanding dimensions has created an immense revolution in the human life. Therefore, the concept of globalization has a very important place in academic circles of economic and social researches (Krasner, 2001). Serious attempts have been made to understand its impact .from all possible aspects.

The most important factor in the impact of globalization is the socio-economic relations of the various stakeholders. The socio-economic development of any country depends on such relations. Throughout human history, societies have been dealing with each other in different ways and have formed all kinds of relations. As per compatibility with the globalization, the social and economic relations have been conformed.

The need is profoundly felt in the developing countries of the world. Pakistan is a developing country where socio-economic development is still in initial process. The interdependency on economically strong countries has made this a slow process. The socio-economic indicators of the country are not good enough. Pakistan is loosing ground

as compared to other countries of the region. Pakistani rupee is loosing the credibility against the foreign currencies of the developed world. The high prices of fuel have hampered the socio-economic development of the common strata of the society. The gap between rich and poor is soaring wide.

\section{Definition of Globalization}

Globalization has been defined in various ways and with different approaches. For example: as an idea, a pattern or project, a process of human history, a probable future, a situation, and finally, as a trend (Nahavandian, 2007). There is not one single definition of the term of globalization. Everyone has seen it in his/her point of view. Therefore, there are different opinions about it (Salimi, 2005). Different writers have different views regarding the definition of globalization. The most important explanation about the concept has been presented by Jan Aart Scholte (Scholte, 2000). Scholte has given five definitions of globalization in the literature. His points are quite relevant to the issue of globalization. The points are as under: 


\section{Globalization as Internationalization}

In this part of the study globalization is simply conceived as the international relations between different countries. The point leads to the concept of exchange for development and greater dependency on each other. Here economy is taken as an exchange of commodities from one border to the next. As a result, the globe becomes a village where business takes place quite easily (Hirst and Thompson, 1996).

\section{Globalization as Liberalization}

In this part of the study the 'globalization' is considered above borders where restrictions are removed with the purpose of creating borderless economy (Scholte, 2000). The researchers who have much supported the idea of dealing with the regulatory business restrictions have included in this type of action.

\section{Globalization as Universalization}

In this section, globalization is considered as a worldwide phenomenon where the transfer of commodities and knowledge is spread in all corners of the world.

\section{Globalization as Westernization or Modernization}

At this point 'globalization' has been considered as a transformation of the cultural values across borders. As a result powerful cultures suppose to imbibe the weak cultures. This system has threatened various existent cultures present in different parts of the world.

\section{Globalization as Deter ritorialization}

At this juncture 'globalization' leads to the concept of reshaping the notion of border, territory, or a country where the movement is free from all the restrictions without any hindrance (Held, McGrew, Goldblatt, Perraton, 1999).

As stated above there are various approaches and definitions of globalization. My understanding of globalization is well-matched to the definition where 'Globalization' is considered as a trend and process which was present in past and is continued to the present time and will be continued in the future as well. All along this process every phenomena and social problem of humans is being changed from the individual, racial, local and national into global level. In this course of action the human lives are more associated and dependent on each other. Consequently, instead of racial, local, and national societies, a single and united global society will be formed.

All the people in this global society have memberships and have a dependency and concern towards it (Ohmae, 1990a). As a result, with mutual support and partnership they try to deal with the difficulties of global society which can be removed (Keohane \& Nye, 
1977). With the definition presented here, the specific changes will appear in the globalization processes. They are as under:

- The elimination of the borders which disconnect the societies of the humans,

- Vanishing the racial, local and national issues and substitute these with the global issues instead,

- The manifestation of global citizenship in place of national citizenship,

- The alliance of all human beings in societies jointly and the extension of communication and to get in touch with among these societies,

- The configuration of global cultures and the encouragement of common values accepted universally ,

- Reduction of racial, local and national institutions on account of the significance of all the global and transnational organizations and institutions,

- The development of international general laws and the empowerment of global organizations,

- Manifestation of global phenomena and concerns. These changes are not restricted to particular areas such as political or economical ones.

However, it encounters all the fields of human life. Therefore, due to the globalization practice, it contains all the human life dimensions and causes of their transformation and changes.

\section{The Social System: Structure and Organization}

Social scientists, whose domain is to analyze the social life, do so at two levels. They are: interpersonal or micro-social level and the group or macro-social level. On the microsocial level they focus on the way individuals relate to one another based on the position that each holds in relation to the other. In this part of the system the socio-economic development takes place at national level. The players of this game are people within a territorial boundary of the country. They usually have the same cultural background and competition is open for all at the national level.

On the macro-social level, social scientists examine the relationships between and amongst groups or nations with multi-cultural opportunities and cultural backgrounds. They focus on the values and rules of behaviour that emerge when people live in various parts of the globe. In this category the concept of socio-economic development emerges at the global level. The competitors are countries and different nations. Powerful nations try to usurp the economic resources and control the weaker. As a result, the economic disparities are vehemently found among the developed and the developing world.

When the social life is observed it has been noted that it takes place within a system, although the system is not rapidly apparent. The social system is an abstraction, a model that illustrates how social relationships work together. Every group, whether it consists of two people or millions of people, is basically a social system. As is characteristic of 
systems, each part is connected to, and depends on each other. It follows that the way each individual in a group influences every other individual in the group. This interconnectedness and interdependence eventually result in shared patterns of behaviour that members come to expect from each other. Knowing what is expected of oneself, and what one can expect of others, makes life much easier and work much more efficient.

The orderly and fairly predictable patterns of interaction that emerge in a social system give that social system structure and organization. Social structure and social organization are terms that refer to the network of organized relationships among the components of a social system. They are patterned and recurring ways in which individuals and groups interact.

\section{Impact of Globalization on Socio-Economic Development}

Human beings are living in diverse and in a variety of groups. Nevertheless, according to sociability of humans, it is essential to maintain relations with others. This kind of need has caused the relations not to be confined to the people and individuals who are living with each other in a group, but also they attempt to relate with the other individuals and the people living in other groups. Such human groups in far past were very small communities like tribes. Their relations appeared as the relations of intertribal. But in the modern time the human groups were conformed as the national units. In this scenario the relations between the national units caused the appearance of the international relations (Kaplan, 1962).

To sustain life, people need a consistent supply of food, sufficient shelter, and clothing for protection from the external elements. These goods are scarce and require combined efforts to obtain. The institution of the economy consists of the patterns of behaviour that revolve around obtaining the scarce resources necessary for survival. Essentially, societal members must decide what to produce, how to distribute and exchange what is produced, and in what manner to consume it?

Pakistan is a developing country. The socio-economic indicators of the country are not encouraging. The economy of the country has remained under the pressure of various external and internal forces. The country has remained under the military dictatorship or Marshal Law most of the period after independence. The elite class of the country has kept themselves disdained from improving the socio-economic condition of the general masses. It is widely believed that Pakistani economy is under direct influence of the various international global donor agencies like IMF, World Bank etc. These agencies have high-jacked the economy. That is the main reason that some unpopular decisions are always imposed on the people of Pakistan. Due to the rising prices of edible commodities the socio-economic condition of the poor is worsening with every passing day.

To determine the impacts of globalization on the socio-economic development, a careful survey of the five determiner indexes of the international system needs to be conducted. 
With due attention to what was brought up as the globalization, the intensive impacts of globalization on these five factors can be foreseen and predicted. The changes which globalization causes are:

(i) With regard to the process of globalization the international players will change. During the previous centuries the states were the only players at first, and then they became the most important international players. In the process of globalization the new players are being activated. In a few cases they replace the states, or the international non-governmental organizations and global organization that usually can disregard the states (Berton, 1999). The most visible characters of new players are their collective, multi-national and global characters. On the contrary, the nation-states emphasized on the national interests of a nation and they attempted to make individual decisions to pursue their own targets. But the new players pay much attention to the interests which different nations take advantages of, and they attempt with cooperation and collectiveness to pursue their targets (Ohmae, 2002). With activation of new players, the role of states and governmental players becomes limited (Ohmae, 1999b). The character of new players in the form of collective, multinational and global forms causes the loss of their validation about their old type of games.

(ii) The other impact of globalization is changing in the structure of international system. Structuration and creation of a new structure is one of the most important impact of globalization. Robertson has argued that we can not understand globalization, without regard to structuration (Robertson,1992). Until the globalization period, the power was centered in specific areas. With the process of globalization the power in the global level went out of the hand of limited members of the states and was distributed in different centers all over the world. Meanwhile, the concept of military power was reduced. And the intellectual, cultural and social dimensions were outstanding. With these two changes, the situation in which only one or two super powers exist and others have to obey them began to change. With changing in power concept, the different canon and institutions of power would be activated and affected. With the distribution of power, the superiority and sovereignty would be removed. A kind of equilibrium of power would be conformed. As a result, cooperation and collective decision making related to issues of human society and human interests would be more important. This will also lead to minimum competition and maximum co-operation.

(iii) Another impact of globalization is the elimination of limited borders which makes the global boundaries of international system in all dimensions. Before the twentieth century, the borders of international system was limited and confined to the continents. After the twentieth century, gradually the borders of international system changed into global ones and a world system appeared. 
Wallerstein has described that the world is the social system which is made up of various different people with different norms, cultures, and behaviours. As a result, tension, division, and conflicts are unavoidable (Wallerstein, 1974).

(iv) In the past, states and governments emphasizing on national rules and laws could govern their affairs. Before the impact of globalization processes, they emphasized on their national interests. The laws with the aim of acquisition of national interests were collected and executed. Every nation had various laws different from other laws (of other nations) and acted upon them. Implementation of different laws led to conflicts and contradiction among nations.

(v) In the past, mostly international system was military, security and political. Its indicators and elements determined the compatible relations among the players inside this system. The change that occurs after the globalization process takes place is that the military, security and political essence of relations among these players fades away and economical, social and cultural essence conquered their domains. Therefore, one can say that the international system in the process of globalization finds and gets the economical and socio-cultural essence. In these conditions the economical and cultural elements and indexes can determine the relations and the appropriateness among the different countries (Ohmae, 1990a).

\section{Conclusion}

Globalization has many faces. It is the process in which the people from different parts with diversified cultural norms are united into a single society. Globalization is considered as a driving force to socio-economic development. The concept of business has been reshaped due to the global village system. The most important point of the impact of globalization is the socio-economic relations of the various stakeholders. The socio-economic development of a country mostly depends on such relations. It has both positive and negative effects. On one way it has reshaped the world as a global village. On the contrary, it has divided the world into two categories i.e. developed and underdeveloped world. The weaker is going to be weaker due to limited available resources. Given that the stronger has the capability to divert the things at its own disposal. Pakistani economy is loosing its ground as compared with other countries of the region. As a result, Pakistani rupee is loosing the credibility against the foreign currency. The high prices of fuel have hampered the socio-economic development of the common strata of the society. The gap between rich and poor is too high due to the pressure of globalization.

\section{End Notes}


1 Scholte, Jan Aart (2000) Globalization: A Critical Introduction, New York, St. Martin's, pp.15-17

${ }^{2}$ Ibid. p. 16.

${ }^{3}$ Berton, Peter (1999) International Negotiation: Actors Structure/Process Values, New York, Palgrave Macmillan: Hardcover, Chap. 9.

${ }^{4}$ Wallerstein, Immanuel (1974) The Modern World-System, New York, Academic Press, pp. 347-57.

${ }^{5}$ Ohmae, K. (1990a) The Borderless World, New York, Harper Collins Publisher, p. ix.

\section{References}

Bhagwati, Jagdish (2004) In Defense of Globalization, New York, Oxford University Press.

Croucher, Sheila L. (2004) Globalization and Belonging: The Politics of Identity a Changing World, Maryland, Rowman \& Littlefield.

Held, David, McGrew, Anthony, Goldblatt, David, and Perraton, Jonathan (1999) Global Transformations: Politics, Economics and Culture, Stanford, Stanford University Press.

Hirst, Paul and G. Thompson (1996) Globalization in Question, Cambridge, Polity Press.

Kaplan, Morton (1962) System and Process in International Politic, New York, Wily.

Keohane, R. \& J. Nye (1977) Power and Interdependence, Boston, Little Brow.

Krasner, S. (2001) "Globalization Power and Authority” In American Political Science Association Annual Meeting, San Francisco, August/September.

Modelski, George (1972) Principles of World Politics, New York, Free Press.

Nahavandian, Mohammad (2007) We and Globalization, Tehran, National Institute for Globalization Studies. (In Persian Language)

Ohmae, K. (2002) "Globalization Region and Economics" In Conference for Globalization and Policy Research, UCLA, January.

Ohmae, K. (1990a) The Borderless World, New York, Harper Collins Publisher.

Ohmae, K. (1990b) The Rise of Region State, Foreign Affairs, Spring. 
Robertson, R. (1992) Globalization Social Theory and Global Culture, London, Sage.

Salimi, H. (2005) Contending Theories on Globalization, Tehran, SAMT. (In Persian Language)

\section{Bibliography}

Giddens, Anthony (1990) The Consequences of Modernity, Stanford, Stanford University Press.

Scholte, Jan Aart (1996) "Beyond the Buzzword: Towards a Critical Theory of Globalization" In Eleonore Kofman and Gillians Young (ed.), Globalization: Theory and Practice. London, Pinter.

\footnotetext{
Ahmed Ali Brohi is Assistant Professor, Department of Sociology, University of Sindh, Jamshoro.

Dr. Saima Sheikh is Assistant Professor, Department of Sociology, University of Sindh, Jamshoro.
} 